\title{
Peran Financial Distress dalam Pengaruh Konservatisme Akuntansi terhadap Tax Avoidance
}

\author{
Natania Aurielle Gunarto ${ }^{1}$ \\ Priyo Hari Adi \\ 1,2Fakultas Ekonomika dan Bisnis Universitas Satya Wacana, Indonesia \\ *Correspondences : priyo.adi@uksw.edu
}

\begin{abstract}
ABSTRAK
Penelitian terkait pengaruh konservatisme akuntansi terhadap tax avoidance telah banyak dilakukan namun belum mempertimbangkan peran financial distress dalam pengaruh tersebut. Penelitian bertujuan untuk menguji pengaruh konservatisme akuntansi terhadap tax avoidance yang dimoderasi oleh financial distress. Penelitian ini merupakan penelitian kuantitatif pada perusahaan sektor barang baku yang terdaftar di BEI pada periode 2015-2019. Jumlah sampel sebanyak 56 sampel dari 95 populasi diperoleh melalui teknik purposive sampling. Data penelitian merupakan data sekunder berupa laporan keuangan dan laporan tahunan masing-masing perusahaan dan dianalisis menggunakan MRA (Moderated Regression Analysis). Hasil penelitian menunjukkan bahwa konservatisme akuntansi berpengaruh positif tidak signifikan terhadap tax avoidance dan financial distress akhirnya tidak mampu memoderasi pengaruh konservatisme akuntansi terhadap tax avoidance.
\end{abstract}

Kata Kunci: $\quad$ Konservatisme Akuntansi; Financial Distress; Tax Avoidance; Pajak Perusahaan.

\section{The Role of Financial distress in The Effect of Accounting Conservatism on Tax avoidance}

\begin{abstract}
Many studies related to the effect of accounting conservatism on tax avoidance have been carried out but have not considered the role of financial distress in this influence. This study aims to examine the effect of accounting conservatism on tax avoidance moderated by financial distress. This research is a quantitative research on raw goods sector companies listed on the IDX in the 2015-2019 period. A total of 56 samples from 95 populations were obtained through purposive sampling technique. Research data is secondary data in the form of financial statements and annual reports of each company and analyzed using MRA (Moderated Regression Analysis). The results showed that accounting conservatism had no significant positive effect on tax avoidance and financial distress was ultimately unable to moderate the effect of accounting conservatism on tax avoidance.
\end{abstract}

Keywords: Accounting Conservatism; Financial Distress; Tax Avoidance; Corporate Tax.

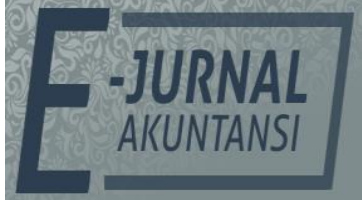

e-ISSN 2302-8556

Vol. 32 No. 2

Denpasar, Februari 2022

Hal. 280-294

DOI:

10.24843/EJA.2022.v32.i02.p01

PENGUTIPAN:

Gunarto, N. A. \& Adi, P. H.

(2022). Peran Financial

Distress dalam Pengaruh

Konservatisme Akuntansi terhadap Tax Avoidance.

E-Jurnal Akuntansi, 32(2), 280-294

RIWAYAT ARTIKEL:

Artikel Masuk:

2 Desember 2021

Artikel Diterima:

13 Februari 2022

Artikel dapat diakses : https://ojs.unud.ac.id/index.php/Akuntansi/index 


\section{PENDAHULUAN}

Perusahaan sebagai wajib pajak memiliki kewajiban perpajakan yang meliputi menghitung, menyetor, dan melaporkan pajak terutang sesuai dengan ketentuan yang berlaku. Meskipun demikian, pajak merupakan beban yang akan mengurangi laba bersih perusahaan sehingga seringkali perusahaan berupaya untuk melakukan manajemen pajak. Salah satu langkah dalam manajemen pajak adalah penghindaran pajak atau tax avoidance yang merupakan upaya legal dan tidak melanggar peraturan perundang-undangan (Windaryani \& Jati, 2020). Sifatnya yang legal akhirnya menjadikan tax avoidance sebagai solusi umum untuk mengefisiensi beban pajak sehingga tax avoidance menjadi topik yang menarik untuk diteliti.

Lebih lanjut, salah satu hal yang menjadi masalah dan perlu mendapat perhatian dalam tax avoidance adalah tentang perilaku akuntansi yang konservatif karena dapat mempengaruhi nilai yang tersaji dalam laporan keuangan dan penentuan kebijakan, termasuk kebijakan di bidang perpajakan seperti tax avoidance (Pramudito \& Sari, 2015). Meskipun telah banyak penelitian yang menguji pengaruh konservatisme akuntansi terhadap tax avoidance namun masih diperoleh hasil yang inkonsisten. Sarra (2017), Swandewi \& Noviari (2020), dan Windaryani \& Jati (2020) menemukan bahwa konservatisme akuntansi memiliki pengaruh negatif terhadap tax avoidance. Sementara itu, Sundari \& Aprilina (2017) menyampaikan adanya pengaruh konservatisme akuntansi terhadap tax avoidance secara positif di perusahaan manufaktur. Pramudito \& Sari (2015) selanjutnya mengungkapkan bahwa tax avoidance tidak dipengaruhi oleh konservatisme akuntansi.

Terjadinya inkonsistensi hasil riset terdahulu mendorong peneliti untuk mengkaji ulang pengaruh konservatisme akuntansi terhadap tax avoidance. Konservatisme akuntansi diduga bukanlah variabel yang dapat berdiri sendiri dan pengaruhnya terhadap tax avoidance dinilai dapat dipengaruhi oleh hal lain. Windaryani \& Jati (2020) dalam penelitiannya menyarankan untuk menambahkan variabel financial distress (kesulitan keuangan) dalam mengukur tax avoidance. Terkait hubungan financial distress dan konservatisme akuntansi, Lawal \& Hassan (2021) melakukan penelitian menggunakan kendala keuangan sebagai variabel moderasi dan menyatakan bahwa kendala keuangan dapat memoderasi pengaruh konservatisme akuntansi terhadap efisiensi investasi secara signifikan. Konservatisme akuntansi dan kendala keuangan bersifat saling berlawanan sehingga semakin tinggi kebutuhan pendanaan perusahaan (mengalami financial distress) maka semakin rendah praktik unconditional conservatism. Berdasarkan kaitan financial distress terhadap konservatisme akuntansi dan tax avoidance, peneliti ingin mengetahui peran financial distress dalam memoderasi pengaruh konservatisme akuntansi terhadap tax avoidance.

Secara umum, penelitian sebelumnya mengenai pengaruh konservatisme akuntansi terhadap tax avoidance telah banyak dilakukan pada berbagai sektor industri. Studi ini dilakukan pada industri sektor barang baku dengan pertimbangan adanya kasus tax avoidance yang pernah dilakukan oleh perusahaan yang termasuk dalam sektor industri tersebut. PT. Toba Pulp Lestari Tbk. (INRU) diduga telah melakukan tax avoidance melalui skema pengalihan laba ke salah satu perusahaan pemasarannya yang berada di tax haven country yakni Makau 
(Pratama, 2020). Praktik tersebut nampaknya telah dilakukan sejak tahun 2007 hingga 2016 dan menimbulkan potensi kebocoran pajak negara sebesar Rp. 1,9 triliun. Pada tahun 2021, INRU telah mengalami perubahan dari sektor industri dasar menjadi sektor barang baku sesuai pengklasifikasian terbaru oleh Bursa Efek Indonesia (BEI). Meskipun demikian, dasar pengklasifikasian kedua sektor serupa sehingga kasus INRU yang terjadi sebelum tahun 2021 masih dianggap relevan dengan pemilihan objek penelitian yang berdasar pada pengklasifikasian terbaru (BEI, 2021).

Penelitian akan menelaah dua persoalan yakni pengaruh konservatisme akuntansi terhadap tax avoidance dan pengaruh konservatisme akuntansi terhadap tax avoidance yang dimoderasi oleh financial distress. Hasil penelitian diharapkan dapat berkontribusi secara praktis dalam memberikan bahan pertimbangan dan evaluasi bagi fiskus dalam penyusunan peraturan perpajakan dan penanganan kasus tax avoidance. Selain itu, penelitian juga diharapkan dapat berkontribusi dalam memberikan pemahaman bagi perusahaan untuk melakukan efisiensi pajak dengan sewajarnya. Secara teoritis, penelitian diharapkan dapat berkontribusi memberikan bukti nyata pengaruh konservatisme akuntansi terhadap tax avoidance dan peran financial distress dalam memoderasi pengaruh tersebut. Lebih lanjut, penelitian juga diharapkan dapat menambah literatur perpajakan dan menjadi referensi penelitian selanjutnya.

Tax avoidance mengacu pada upaya legal untuk mengurangi beban pajak terutang yang masih berada di bawah lingkup peraturan yang berlaku (Zulfiara \& Ismanto, 2019). Upaya pengurangan beban pajak tersebut dapat dilakukan melalui pemanfaatan kelemahan yang ada dalam ketentuan perpajakan maupun perbedaan ketentuan perpajakan antar yurisdiksi (Richardson et al., 2015b). Lebih lanjut, Lenz (2018) mengadaptasi penjelasan Lietz (2013) menyebutkan bahwa terdapat 3 (tiga) elemen kunci dalam tax avoidance yaitu responsible, aggressive, dan abusive. Responsible tax avoidance mengacu pada tax avoidance yang bersifat perfectly legal. Sementara itu aggressive tax avoidance digolongkan sebagai probably legal dan abusive tax avoidance sudah tergolong illegal. Penelitian ini selanjutnya akan mengacu pada responsible tax avoidance yang masih bersifat legal.

Suandy (2016) menjelaskan bahwa tax avoidance sejatinya termasuk suatu rekayasa perpajakan yang dapat digunakan sebagai perencanaan pajak. Meskipun demikian, Nadhifah \& Arif (2020) menyampaikan bahwa perencanaan pajak dapat berubah menjadi penghindaran pajak apabila terdapat intensi untuk memperoleh keuntungan tertentu. Hal ini sesuai yang disampaikan oleh Organization for Economic Cooperation and Development (OECD) tentang 3 (tiga) karakteristik tax avoidance yaitu adanya pemanfaatan celah ketentuan perpajakan untuk tujuan tertentu, memiliki unsur artifisial, dan adanya kerahasiaan antara para konsultan dengan wajib pajak (Suandy, 2016). Hingga kini sifat tax avoidance masih menjadi perdebatan karena di satu sisi merugikan negara namun di lain sisi dianggap legal dan tidak melanggar peraturan yang ada.

Sementara itu, konservatisme akuntansi merupakan prinsip akuntansi yang mempercepat pengakuan beban dan kerugian serta memperlambat pengakuan pendapatan dan keuntungan (Hajawiyah et al., 2020). Perilaku akuntansi yang konservatif umumnya digunakan untuk meningkatkan nilai deferred income yang dapat mempengaruhi besar kecilnya pajak terutang yang 
harus dibayar perusahaan (Ferramosca \& Ghio, 2018). Penggunaan konservatisme akuntansi akan menyebabkan peningkatan nilai beban dan penurunan nilai laba bersih dan pajak terutang sehingga dinilai tidak dapat mencerminkan laporan keuangan yang semestinya. Sementara itu, Susanti (2018) menyampaikan bahwa penerapan akuntansi yang konservatif merupakan langkah kehati-hatian perusahaan terhadap ketidakpastian dan risiko bisnis. Konservatisme akuntansi dapat digunakan untuk menghambat perilaku oportunistik manajer untuk melaporkan laba perusahaan yang terlalu besar (Sjahputra, 2019). Perbedaan argumen mengenai manfaat prinsip konservatisme akuntansi hingga kini masih menjadi perdebatan diantara peneliti, terlebih apabila dikaitkan dengan kondisi financial distress.

Financial distress atau kesulitan keuangan terjadi ketika perusahaan mengalami kekurangan dan ketidakcukupan dana untuk melanjutkan hidupnya (Nadhifah \& Arif, 2020). Cita \& Supadmi (2019) menyebutkan bahwa financial distress dapat menjadi indikasi awal kebangkrutan sebuah perusahaan yang biasanya disebabkan oleh adanya kewajiban yang terikat kontrak. Dalam masa krisis, perusahaan akan berusaha memenuhi kebutuhan modal untuk menjaga peringkat kredit, memenuhi persyaratan kontrak utang, melunasi utang kepada pihak eksternal, dan menjaga kelangsungan hidup (Richardson et al., 2015b; Swandewi \& Noviari, 2020). Salah satu cara untuk memenuhi kebutuhan modal tersebut adalah melalui penghematan pengeluaran, termasuk pengeluaran dalam bidang perpajakan. Richardson et al. (2015a) dalam Sadjiarto et al. (2020) menyebutkan bahwa financial distress dapat menjadi insentif untuk melakukan tax avoidance. Keuntungan atas tax avoidance yang dirasakan perusahaan dalam kondisi financial distress cenderung lebih besar daripada keuntungan atas penghematan pajak saat kondisi normal.

Penerapan prinsip konservatisme akuntansi dinilai dapat menghasilkan jumlah pajak penghasilan badan terutang yang lebih rendah dibandingkan dengan jumlah semestinya (Saleh et al., 2019). Konservatisme akuntansi dianggap menunda pengakuan pendapatan kena pajak ke tahun pajak selanjutnya dengan cara memperlambat pengakuan pendapatan dan mempercepat pengakuan biaya, melakukan penilaian yang terlalu rendah terhadap aset namun penilaian yang terlalu tinggi terhadap hutang (Martinez, 2021). Lebih lanjut, Ferramosca \& Ghio (2018) juga menyampaikan bahwa penerapan akuntansi yang konservatif dapat menurunkan berbagai biaya seperti biaya agensi dan litigasi. Akibatnya, perusahaan tidak memerlukan lagi upaya pengurangan pajak melalui tax avoidance karena pajak terutang yang dibayarkan sudah rendah. Penelitian sebelumnya oleh Windaryani \& Jati (2020) menemukan adanya pengaruh negatif konservatisme akuntansi terhadap tax avoidance. Sarra (2017), Sjahputra (2019), dan Swandewi \& Noviari (2020) bahkan menyatakan bahwa pengaruh negatif tersebut adalah signifikan.

$\mathrm{H}_{1}$ : Konservatisme akuntansi berpengaruh negatif signifikan terhadap tax avoidance.

Meskipun demikian, penerapan konservatisme akuntansi akan lebih rendah pada perusahaan yang tengah mengalami financial distress tingkat tinggi. Hal ini dikarenakan perusahaan tidak ingin membuat investor kecewa dengan menampilkan nilai laba yang terlalu rendah sehingga perusahaan memilih untuk 
menyembunyikan laba tersebut melalui penerapan konservatisme akuntansi yang rendah (Sholikhah \& Suryani, 2020). Meskipun demikian, tingkat financial distress yang tinggi selanjutnya menyebabkan perusahaan perlu melakukan penghematan, terkhusus penghematan beban terbesar yakni beban pajak, agar dapat membiayai pembiayaan eksternal yang salah satu caranya melalui penerapan tax avoidance (Edwards et al., 2016 dalam Chaudhry et al., 2017). Richardson et al. (2015b) berpendapat bahwasanya kebijakan yang terlihat berisiko pada kondisi normal akan terlihat menggiurkan dan berpotensi meningkatkan keuntungan pada kondisi financial distress.

Berdasarkan hipotesis sebelumnya, diketahui bahwa penerapan konservatisme akuntansi yang rendah menyebabkan tingginya penerapan tax avoidance, dan sebaliknya. Kondisi financial distress tetap akan membuat perusahaan semakin yakin untuk melakukan tax avoidance karena beban yang ditanggung semakin besar. Perusahaan perlu melakukan penghematan supaya dapat bertahan hidup (Nadhifah \& Arif, 2020). Sebagai variabel moderator, financial distress berperan sebagai auxiliary independent variable (variabel independen tambahan) untuk mengubah hubungan $X$ terhadap Y (Wu \& Zumbo, 2008). Lawal \& Hassan (2021) menemukan bahwa kendala keuangan dapat menjadi moderator yang signifikan dalam hubungan konservatisme akuntansi (variabel independen) dan efisiensi investasi (variabel dependen) sehingga peneliti menduga bahwa peran moderasi tersebut juga berlaku untuk variabel dependen tax avoidance.

$\mathrm{H}_{2}$ : Financial distress memperkuat pengaruh konservatisme akuntansi terhadap tax avoidance.

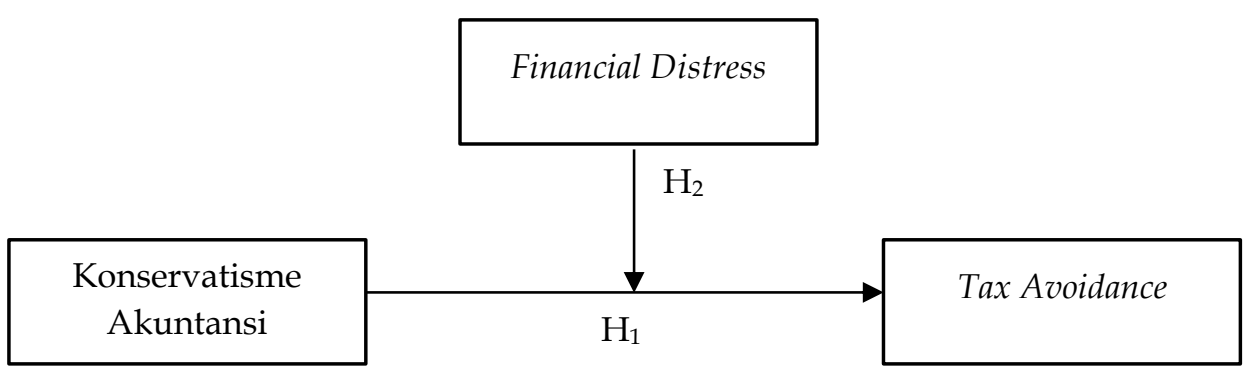

Gambar 1. Model Penelitian

Sumber: Data Penelitian, 2021

\section{METODE PENELITIAN}

Penelitian dilakukan terhadap perusahaan sektor barang baku yang terdaftar di Bursa Efek Indonesia (BEI). Total populasi penelitian sebesar 95 (sembilan puluh lima) perusahaan akan diseleksi menggunakan teknik purposive sampling untuk menghasilkan 56 (lima puluh enam) sampel perusahaan. Kriteria yang digunakan dalam pengambilan sampel adalah perusahaan sektor barang baku yang terdaftar di BEI pada tahun 2015 hingga 2019, perusahaan yang menerbitkan laporan keuangan dan laporan tahunan, serta menyajikan laporan keuangan dalam mata uang rupiah. Data penelitian menggunakan data kuantitatif sekunder berupa laporan keuangan dan laporan tahunan periode 2015 hingga 2019 yang dapat diperoleh melalui situs resmi BEI maupun situs resmi masingmasing perusahaan. Pemilihan periode penelitian sepanjang 5 (lima) tahun 
didasari oleh saran Sundari \& Aprilina (2017) untuk memperpanjang periode penelitian lebih dari 3 (tiga) tahun untuk memberikan hasil penelitian yang lebih maksimal. Sementara itu, tahun 2020 tidak dipertimbangkan sebagai periode penelitian karena adanya pemberian insentif perpajakan terkait pandemi COVID19 yang dinilai dapat mengganggu hasil penelitian yang sebenarnya.

\section{Tabel 1. Perhitungan Jumlah Sampel}

\begin{tabular}{lc}
\hline \multicolumn{1}{c}{ Kriteria } & Jumlah \\
\hline Total populasi perusahaan sektor barang baku & 95 \\
Perusahaan yang tidak memenuhi kriteris & $(39)$ \\
Jumlah sampel akhir & 56 \\
\hline
\end{tabular}

Sumber: Data Penelitian, 2021

Tax avoidance merupakan variabel dependen dalam penelitian yang didefinisikan sebagai upaya meminimalisir beban pajak oleh perusahaan dengan memanfaatkan celah kelemahan dalam peraturan perpajakan (Richardson et al., 2015b). Variabel akan diproksikan dengan Book Tax Differences (BTD) karena dapat menggambarkan selisih antara laba fiskal dan laba akuntansi. BTD akan dinyatakan dalam skala rasio dengan rumus sebagai berikut (Cabello et al., 2019) : $B T D=\frac{E B I T-T I}{T A}$

Keterangan:

$B T D=$ Book Tax Difference atau perbedaan laba fiskal dan laba akuntansi

EBIT = Laba sebelum bunga dan pajak

$T I \quad=$ Penghasilan kena pajak

TA $\quad=$ Total aset

Variabel independen dalam penelitian adalah konservatisme akuntansi. Konservatisme akuntansi berkaitan dengan kecenderungan untuk mempercepat pengakuan beban dan kerugian namun memperlambat pengakuan pendapatan dan keuntungan hingga tingkat keterjadiannya signifikan (Hajawiyah et al., 2020). Berdasarkan Givoly \& Hayn (2000), konservatisme akuntansi dinyatakan dengan rumus:

$A C_{c, y}=\left(I B E I_{c, y}+D E P_{c, y}-C F O_{c, y}\right) x(-1)$

Keterangan:

$A C_{\mathrm{c}, \mathrm{y}}=$ Konservatisme akuntansi pada perusahaan $\mathrm{c}$ tahun $\mathrm{y}$

$I B E I_{c, y}=$ Laba bersih sebelum extraordinary item perusahaan $\mathrm{c}$ tahun $\mathrm{y}$

$D E P_{c, y}=$ Beban depresiasi perusahaan $\mathrm{c}$ tahun $\mathrm{y}$

$C F O_{c, y}=$ Arus kas dari aktivitas operasi perusahaan c tahun $\mathrm{y}$

Kriteria penentuan tingkat konservatisme akuntansi ditentukan melalui hasil persamaan bernilai positif yang mengindikasikan tingginya tingkat konservatisme akuntansi sedangkan hasil persamaan yang bernilai negatif akan mengindikasikan rendahnya konservatisme akuntansi. Lebih lanjut, konservatisme akuntansi akan dinyatakan dalam skala rasio.

Financial distress yang merupakan variabel moderasi dalam penelitian dapat didefinisikan sebagai keadaan perusahaan yang tidak memiliki kecukupan dana untuk melanjutkan hidupnya (Nadhifah \& Arif, 2020). Pengukuran financial distress dilakukan menggunakan Altman's Z-Score yang dinyatakan dalam skala rasio. Altman's Z-Score Model dirumuskan sebagai berikut Altman (1968).

$Z S M=0,012 X_{1}+0,014 X_{2}+0,033 X_{3}+0,006 X_{4}+0,999 X_{5}$ 


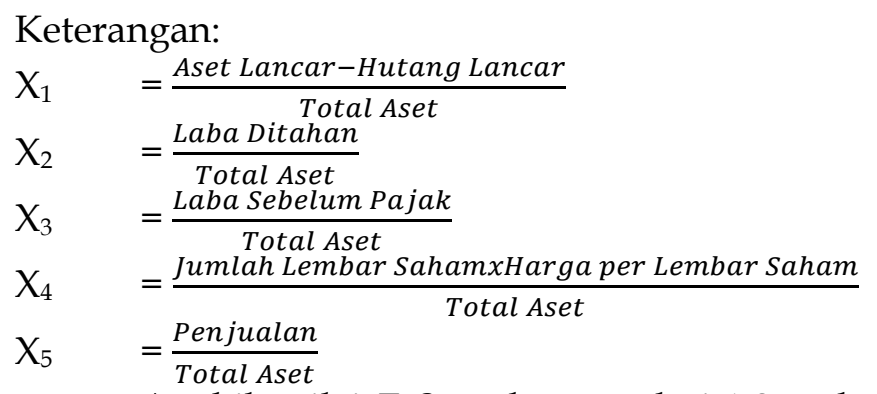

Apabila nilai Z-Score kurang dari 1,8 maka dikatakan bahwa perusahaan tengah menghadapi financial distress dan memiliki peluang besar akan bangkrut. Nilai Z-Score 1,8 hingga 2,99 mengindikasikan bahwa perusahaan berada dalam grey area dan terdapat kemungkinan moderat bahwa perusahaan akan bangkrut. Sementara itu, nilai Z-Score diatas 2,99 mengindikasikan adanya safe zone dalam perusahaan dan kemungkinan kecil bangkrut.

Penelitian memiliki 3 (tiga) variabel yang saling berhubungan yakni konservatisme akuntansi yang mewakili variabel independen, financial distress yang mewakili variabel moderasi, dan tax avoidance yang mewakili variabel dependen. Ketiga variabel akan dianalisis menggunakan teknik path analysis yang merupakan pengembangan teknik regresi yang dapat memberikan penafsiran kausalitas antar variabel (Purnaningsih \& Noviari, 2019). Proses analisis data dilakukan dengan menggunakan software IBM SPSS Statistic 26 dan tools PROCESS MACRO for SPSS pada taraf signifikansi (a) sebesar $5 \%$. Penelitian akan mengacu pada pendekatan pengujian moderasi oleh Hayes (2015). Persamaan path analysis disajikan sebagai berikut:

$B T D=\alpha+\beta_{2} A C+\beta_{3} Z S M+\beta_{4} A C Z S M+\varepsilon$

Keterangan:

AC = Proksi konservatisme akuntansi (variabel independen)

BTD = Proksi tax avoidance (varibel dependen)

$\mathrm{ZSM}=$ Proksi financial distress (variabel moderasi)

$\beta_{2}, \beta_{3}=$ Koefisien regresi konservatisme akuntansi dan financial distress

$\beta 4=$ Koefisien moderasi

$\varepsilon \quad=$ Residual

\section{HASIL DAN PEMBAHASAN}

Pengujian diawali dengan melakukan analisis statistik deskriptif untuk memberikan gambaran awal tentang sifat data melalui nilai minimum, nilai maksimum, rata-rata, dan standar deviasi dari seluruh variabel.

\section{Tabel 2. Hasil Analisis Deskriptif}

\begin{tabular}{lccccc}
\hline Variabel & $\mathrm{N}$ & Mean & Min & Max & Standard Deviation \\
\hline BTD & 280 & 0,019 & $-0,108$ & 0,259 & 0,028 \\
AC & 280 & $-41,689$ & $-3788,933$ & 1839,504 & 485,017 \\
ZSM & 280 & 0,876 & $-0,045$ & 8,430 & 1,047 \\
\hline
\end{tabular}

Sumber: Data Penelitian, 2021

Tabel 2 menyatakan bahwa terdapat 280 (dua ratus delapan puluh) data pengamatan dari 56 (lima puluh enam) sampel penelitian. Book tax differences (BTD) sebagai proksi tax avoidance memiliki nilai terendah sebesar $-0,108$, nilai tertinggi sebesar 0,259 , dan nilai rata-rata sebesar 0,019 . Nilai rata-rata yang 
bernilai positif menunjukkan keberadaan laba fiskal yang lebih rendah dibandingkan laba akuntansi sehingga menandakan penerapan tax avoidance oleh perusahaan secara rata-rata. Laba fiskal umumnya memiliki nilai yang lebih tinggi daripada laba akuntansi karena adanya undeductiable expenses yang tidak diperkenankan diakui oleh fiskal. Lebih lanjut, tax avoidance memiliki nilai standar deviasi sebesar 0,028 yang lebih tinggi daripada nilai rata-rata sehingga mengindikasikan tingginya variasi data.

Konservatisme akuntansi yang diproksikan dengan AC memiliki nilai minimum sebesar -3788,933 miliar rupiah dan nilai maksimum sebesar 1839,504 miliar rupiah. Berbeda dengan variabel sebelumnya, nilai rata-rata menunjukkan nilai negatif sebesar $-41,689$ yang menggambarkan rendahnya penerapan prinsip konservatisme akuntansi pada rata-rata perusahaan sampel. Sementara itu, nilai standar deviasi menunjukkan penyimpangan yang cukup tinggi terhadap nilai rata-rata yakni sebesar 485,017 miliar rupiah. Nilai standar deviasi yang lebih besar daripada nilai rata-rata juga mengindikasikan tingginya keragaman data dan adanya nilai ekstrim pada variabel konservatisme akuntansi.

Variabel financial distress memiliki nilai minimum -0,045 dan nilai maksimum sebesar 8,430. Nilai terendah dimiliki oleh PT Kertas Basuki Rachmat Indonesia Tbk sedangkan nilai tertinggi dimiliki oleh PT Alakasa Industrindo Tbk. Apabila melihat nilai rata-rata sebesar 0,876 yang lebih rendah dari 1,8 maka dapat disimpulkan bahwa rata-rata perusahaan tengah menghadapi financial distress dan diperhadapkan dengan kebangkrutan. Meskipun demikian, kondisi tersebut tidak murni berasal dari kendala yang tengah dihadapi perusahaan namun juga terpengaruh oleh faktor unbalanced data. Apabila perusahaan belum terdaftar pada tahun tertentu selama periode penelitian dan apabila tidak terdapat laporan keuangan maupun laporan tahunan yang dapat diteliti maka nilai data dianggap 0 . Serupa dengan variabel tax avoidance, nilai standar deviasi yakni sebesar 1,047 yang lebih tinggi daripada nilai rata-rata menggambarkan variasi data yang beragam.

Pengujian dilanjutkan dengan uji asumsi klasik yang termasuk salah satu syarat yang harus dipenuhi dalam pemodelan regresi dan pengembangannya. Pengujian bertujuan untuk memberikan keyakinan terhadap ketepatan dan keakuratan model persamaan. Pengujian akan dilakukan melalui 4 (empat) jenis pengujian yakni uji normalitas, uji multikolinearitas, uji heteroskedastisitas, dan uji autokorelasi. Uji normalitas dilakukan dengan membandingkan nilai asymptote significance dengan taraf signifikansi (a) sebesar 0,05 dan bertujuan untuk mengetahui normalitas residual data penelitian. Jenis uji normalitas yang akan digunakan adalah uji Kolmogorov-Smirnov karena jumlah sampel penelitian lebih dari 50 sampel.

\section{Tabel 3. Hasil Uji Normalitas Sebelum Remediasi Data}

\begin{tabular}{lr}
\hline & Unstandardized Residual \\
\hline Asymptote significance (2-tailed) & 0,00 \\
\hline Sumber: Data Penelitian, 2021 &
\end{tabular}

Tabel 3 menunjukkan nilai asymptote significance sebesar $0,00 \leq 0,05$ mengindikasikan bahwa data penelitian tidak berdistribusi normal sehingga perlu adanya remediasi data. Remediasi data dilakukan terhadap variabel konservatisme dan financial distress yang paling banyak memiliki nilai ekstrim 
dengan mentranformasikan kedua variabel menjadi bentuk Logaritma 10 (Log10 (x)). Hasil transformasi menujukkan adanya beberapa missing value sehingga data pengamatan yang awalnya berjumlah 280 berkurang menjadi 89 pengamatan untuk masing-masing variabel. Jumlah tersebut selanjutnya akan menjadi dasar dalam melakukan pengujian asumsi dan hipotesis.

Tabel 4. Hasil Uji Normalitas Setelah Remediasi Data

\begin{tabular}{lr}
\hline & Unstandardized Residual \\
\hline Asymptote significance (2-tailed) & 0,198 \\
\hline Sumber: Data Penelitian, 2021
\end{tabular}

Tabel 4 menunjukan bahwa nilai asymptote significance setelah remediasi data sebesar 0,198 > 0,05 yang berarti data telah berdistribusi secara normal sehingga lolos uji normalitas. Uji multikolinearitas bertujuan untuk mengidentifikasi korelasi antar variabel karena model penelitian tidak boleh mengandung korelasi antar variabel (Rosadi \& Waluyo, 2017). Data akan dikatakan lolos uji multikolineartitas apabila nilai VIF (Variance Inflation Factor) kurang dari nilai cut-off yaitu 10.

Tabel 5. Hasil Uji Multikolinearitas

\begin{tabular}{lc}
\hline Variabel & $V I F$ \\
\hline$A C$ & 1,001 \\
$Z S M$ & 1,001 \\
\hline
\end{tabular}

Sumber: Data Penelitian, 2021

Seluruh variabel memiliki nilai $V I F<10$ seperti yang ditunjukan dalam Tabel 5 Apabila diperhatikan, seluruh variabel bahkan memiliki kisaran nilai VIF yang cukup rendah yakni 1 . Oleh sebab itu, dapat diambil kesimpulan bahwa tidak terjadi multikolinearitas atau tidak terdapat korelasi antar variabel.

Pengujian asumsi klaslik dilanjutkan dengan uji heteroskedastisitas yang berkaitan dengan adanya kesamaan varians residual suatu pengamatan ke pengamatan lain. Data dikatakan lolos uji heteroskedastisitas apabila memiliki nilai signifikansi > 0,05 yang mengindikasikan adanya kesamaan varians residual antar pengamatan.

Tabel 6. Hasil Uji Heteroskedastisitas

\begin{tabular}{lc}
\hline Variabel & Nilai Signifikansi \\
\hline$A C$ & 0,798 \\
$Z S M$ & 0,949 \\
\hline
\end{tabular}

Sumber: Data Penelitian, 2021

Berdasarkan data pada Tabel 6, kedua variabel memiliki nilai signifikansi $>0,05$ yakni 0,798 untuk konservatisme akuntansi dan 0,949 untuk financial distress. Hal ini berarti tidak terdapat kecendurungan heteroskedastisitas atau dengan kata lain terdapat kesamaan varians residual satu pengamatan ke pengamatan yang lain. Oleh sebab itu, kedua variabel dikatakan lolos uji heteroskedastisitas.

Pengujian terakhir dalam pengujian asumsi klasik adalah uji autokorelasi yang bertujuan untuk mengetahui korelasi residu antar periode penelitian yang menggunakan data time series. Jenis uji autokorelasi yang dipilih adalah uji Durbin-Watson yang dilakukan dengan membandingkan nilai durbin-watson (d) dengan nilai $d U$ dan 4- $d U$. Data dikatakan tidak memiliki autokorelasi apabila nilai $d$ berada di antara $d U$ dan 4- $d U$. 
Tabel 7. Hasil Uji Autokorelasi

$\begin{array}{cc}\mathrm{dL} & 1,610 \\ \mathrm{dU} & 1,701 \\ \mathrm{~d} & 2,059 \\ 4-\mathrm{dU} & 2,299 \\ 4-\mathrm{dL} & 2,391\end{array}$

Sumber: Data penelitian, 2021

Hasil menyatakan bahwa nilai durbin-watson (d) sebesar 2,059 berada diantara $d U$ dan 4- $d U$. Hal ini mengindikasikan bahwa tidak terdapat korelasi residu antar data pengamatan sehingga dapat dikatakan lolos uji autokorelasi. Pengujian hipotesis diawali dengan menguji pengaruh konservatisme akuntansi terhadap tax avoidance yang mewakili hipotesis pertama $\left(\mathrm{H}_{1}\right)$. Pengujian tersebut dilakukan pertama kali karena konservatisme akuntansi dan tax avoidance merupakan 2 (dua) variabel utama dalam penelitian. Setelah itu, pengujian dilakukan dengan melihat peran financial distress sebagai variabel moderasi dalam mempengaruhi hubungan kedua variabel utama $\left(\mathrm{H}_{2}\right)$ yang meliputi memperkuat atau memperlemah hubungan tersebut.

Tabel 8. Hasil Pengujian Moderasi

\begin{tabular}{lccc} 
& \multicolumn{2}{c}{ Outcome Variabel } & \\
\cline { 2 - 3 } & \multicolumn{2}{c}{ BTD } & \multirow{2}{*}{$R^{2}$ change } \\
\hline Int_l & $-0,002$ & p-value & 0,001 \\
AC & 0,005 & 0,821 & \\
ZSM & $-0,004$ & 0,103 & \\
\hline
\end{tabular}

Keterangan: Int_1 adalah perkalian AC dan ZSM

Sumber: Data Penelitian, 2021

Nilai koefisien pengaruh interaction term (int_1) terhadap BTD bernilai 0,002 sedangkan $p$-value sebesar 0,821 >0,05 yang berarti pengaruh interaction term terhadap tax avoidance adalah negatif dan tidak signifikan. Hal ini menggambarkan bahwa financial distress bukanlah moderator yang signifikan dari pengaruh konservatisme akuntansi terhadap tax avoidance. Selain itu, terdapat nilai perubahan $R$-square ( 2 change) yang dapat mengidentifikasi seberapa besar variasi tambahan yang disumbang oleh interaction term kepada tax avoidance. Nilai perubahan sebesar 0,001 bermakna interaction term akan menyumbang 0,001 atau 0,01\% variasi tambahan terhadap tax avoidance.

Lebih lanjut, Tabel 8 juga menggambarkan pengaruh konservatisme akuntansi terhadap tax avoidance yang mewakili H1. Pengaruh yang positif tidak signifikan digambarkan melalui nilai koefisien yang positif 0,005 dan nilai $p$-value sebesar 0,103 >0,05. Sebaliknya, pengaruh ZSM terhadap BTD memiliki nilai koefisien $-0,004$ dan nilai p-value sebesar 0,538 $>0,05$. Oleh sebab itu, dapat disimpulkan bahwa financial distress memiliki pengaruh negatif tidak signifikan terhadap tax avoidance.

Tabel 9. Conditional Effect Pengujian Moderasi

\begin{tabular}{ccc}
\hline ZSM & Effect & $p$-value \\
\hline$-0,368$ & 0,005 & 0,167 \\
0,000 & 0,005 & 0,103 \\
0,368 & 0,004 & 0,334 \\
\hline
\end{tabular}


Sumber: Data Penelitian, 2021

Tabel 9 menggambarkan tingkat financial distress yang dapat memoderasi pengaruh konservatisme akuntansi terhadap tax avoidance. Nilai ZSM menunjukkan tingkatan financial distress, seperti nilai ZSM sebesar -0,368 menunjukkan tingkat financial distress rendah, nilai 0,000 menunjukkan tingkat moderat, dan nilai 0,368 menunjukkan tingkat tinggi. Dalam tabel terlihat bahwa seluruh tingkatan financial distress memiliki nilai effect positif dan $p$-value $>0,05$. Oleh sebab itu dapat disimpulkan bahwa dalam tingkatan apapun, baik rendah, moderat, maupun tinggi, financial distress berpengaruh positif dan tidak signifikan dalam memoderasi pengaruh konservatisme akuntansi terhadap tax avoidance.

Hasil pengujian $\mathrm{H} 1$ menyatakan bahwa terdapat pengaruh positif namun tidak signifikan antara konservatisme akuntansi terhadap tax avoidance. Sundari \& Aprilina (2017) menjelaskan bahwa pengaruh positif tersebut disebabkan karena prinsip konservatisme akuntansi sering kali sengaja digunakan untuk meminimalkan laba bersih. Perusahaan akan menunda pengakuan keuntungan penjualan dan piutang dagang agar laba bersih periode kini cenderung rendah sehingga beban pajak yang harus dibayarkan pun rendah. Perusahaan juga akan berusaha untuk meningkatkan nilai waktu uang melalui penundaan pengakuan laba supaya dana yang ada dapat digunakan untuk memenuhi kebutuhan lain terlebih dahulu. Oleh sebab itu, dapat dikatakan bahwa perusahaan dengan sengaja memanfaatkan prinsip konservatisme sebagai langkah melakukan tax avoidance.

Meskipun demikian, nilai p-value menunjukkan angka 0,103 > 0,05 sehingga tidak terdapat pengaruh signifikan. Konservatisme akuntansi tidak didesain untuk mengurangi beban pajak dan melakukan tax avoidance sehingga tidak serta-merta berpengaruh pada tendensi perusahaan untuk melakukan tax avoidance. Susanti (2018) menjelaskan bahwa sejatinya prinsip konservatisme akuntansi selaras dengan peraturan perpajakan dengan adanya beberapa kesamaan ketentuan. Ketentuan tersebut terkait dengan larangan pembentukan cadangan kerugian piutang tak tertagih (kecuali bagi perusahaan leasing, perbankan, dan asuransi) dan larangan pengukuran nilai persediaan berdasar metode LIFO (Last In First Out). Pengaruh tidak signifikan konservatisme akuntansi terhadap tax avoidance juga selaras dengan hasil penelitian oleh Pramudito \& Sari (2015) dan Susanti (2018). Berdasarkan hasil pengujian dan analisis maka dapat disimpulkan bahwa $\mathrm{H} 1$ ditolak.

Lebih lanjut, hasil pengujian $\mathrm{H} 2$ menunjukkan bahwa financial distress bukanlah moderator yang signifikan melalui nilai $p$-value int_1 sebesar 0,821 >0,05. Terlebih, hasil dari conditional effect juga menunjukkan bahwa pengaruh konservatisme akuntasi terhadap tax avoidance adalah positif dan tidak signifikan pada seluruh tingkatan financial distress. Pengaruh positif disebabkan oleh adanya insentif yang akan memberikan keuntungan lebih tinggi apabila perusahaan menerapkan tax avoidance saat mengalami kesulitan keuangan. Sejalan dengan yang disampaikan oleh Rachmawati \& Fitriana (2021) dan Sadjiarto et al. (2020), pengurangan beban pajak akan lebih menguntungkan dibandingkan pengurangan biaya-biaya lainnya sehingga ketersediaan sumber pendanaan internal untuk menyelesaikan kewajiban yang berkaitan dengan financial distress akan meningkat. Meskipun demikian, pengaruh positif tersebut tidak signifikan 
karena perusahaan yang sedang mengalami financial distress cenderung menghindari risiko tinggi demi menjaga reputasinya. Valensia \& Khairani (2019) yang menemukan adanya pengaruh tidak signifikan antara financial distress dan tax avoidance menyampaikan bahwa financial distress tidak selalu mengindikasikan tingginya tax avoidance karena praktik tersebut akan berisiko bagi pemegang saham maupun perusahaan sendiri.

Pemilihan financial distress sebagai variabel moderasi mengacu pada penelitian Lawal \& Hassan (2021) yang juga menggunakan konservatisme akuntansi sebagai variabel independen utama dan kendala keuangan sebagai variabel independen tambahan. Meskipun demikian, nampaknya peran kedua variabel independen tersebut tidak cocok digunakan pada variabel dependen tax avoidance. Pengujian H1 menyatakan bahwa tidak terdapat pengaruh signifikan antara konservatisme akuntansi terhadap tax avoidance. Apabila hubungan antar variabel utama tidak terjadi pengaruh signifikan maka efek moderasi dari variabel lain juga tidak dapat dibuktikan. Penelitian Dhamara \& Violita (2018) mengenai pengaruh dewan komisaris terhadap agresivitas pajak yang dimoderasi oleh financial distress menemukan bahwa financial distress gagal menjadi moderator yang signifikan karena pengaruh variabel utama yakni dewan komisaris dan agresivitas pajak tidak signifikan. Oleh karena itu, dapat disimpulkan bahwa financial distress tidak akan memperkuat atau memperlemah pengaruh konservatisme akuntansi terhadap tax avoidance sehingga $\mathrm{H} 2$ ditolak.

\section{SIMPULAN}

Penelitian bertujuan untuk menguji pengaruh konservatisme akuntansi terhadap tax avoidance dan menguji peran financial distress dalam memoderasi pengaruh konservatisme akuntansi terhadap tax avoidance. Hasil studi menyatakan bahwa konservatisme akuntansi berpengaruh positif namun tidak signifikan terhadap tax avoidance dan financial distress bukanlah moderator yang signifikan sehingga tidak memiliki peran signifikan dalam memoderasi pengaruh konservatisme akuntansi terhadap tax avoidance. Kondisi financial distress dianggap sebagai kondisi yang rawan sehingga perusahaan akan lebih berhati-hati dan mencari jalan aman dalam melakukan aktivitas apapun. Perusahaan tidak melakukan tindakan yang berisiko seperti tax avoidance karena dianggap dapat menimbulkan risiko dan kerugian yang lebih besar, baik bagi perusahaan maupun para pemegang saham. Berdasarkan hasil pengujian, akhirnya dapat disimpulkan bahwa konservatisme akuntansi tidak selalu menjadi alasan diterapkannya tax avoidance oleh perusahaan, terlebih apabila perusahaan tengah mengalami financial distress.

Penelitian memiliki keterbatasan pemilihan software analisis yang dapat memberikan hasil konsisten. Software IBM SPSS Statistics 26 yang digunakan ternyata tidak dapat memberikan hasil yang konsisten terkait uji normalitas sehingga dapat berdampak pada interprestasi data yang kurang valid. Peneliti menyarankan untuk menggunakan software analisis lain seperti AMOS, EViews, atau $R$ statistic. Penelitian juga terkendala dengan banyaknya data outlier akibat penggunaan unbalanced data sehingga peneliti menyarankan penggunaan balanced data agar tidak banyak terjadi pengurangan sampel dan hasil interpretasi menjadi lebih akurat. Lebih lanjut, dalam penelitian ini financial distress gagal memoderasi pengaruh konservatisme akuntansi terhadap tax avoidance sehingga peneliti 
menyarankan untuk pengukuran lain pada financial distress, seperti biaya tidak langsung. Biaya tidak langsung dianggap sebagai alat ukur yang lebih mendalam agar dapat memberikan pengaruh yang lebih signifikan serta belum banyak dikembangkan pada penelitian di negara berkembang (Farooq \& Jibran, 2017).

\section{REFERENSI}

Altman, E. I. (1968). Financial ratios, discriminant analysis and the prediction of corporate bankruptcy. The Journal Of Finance, XXIII(4), 589-609. https:// doi.org/10.1111/j.1540-6261.1968.tb00843.x

BEI. (2021). Klasifikasi Sektor dan Subsektor. PT. Bursa Efek Indonesia. https://www.idx.co.id/produk/saham/

Cabello, O. G., Gaio, L. E., \& Watrin, C. (2019). Tax avoidance in managementowned firms: Evidence from Brazil. International Journal of Managerial Finance, 15(4), 580-592. https:// doi.org/10.1108/IJMF-04-2018-0117

Chaudhry, N., Au Yong, H. H., \& Veld, C. (2017). Tax avoidance in response to a decline in the funding status of defined benefit pension plans. Journal of International Financial Markets, Institutions and Money, 48, 99-116. https://doi.org/10.1016/j.intfin.2016.12.004

Cita, I. G. A., \& Supadmi, N. L. (2019). Pengaruh financial distress dan good corporate governance pada praktik tax avoidance. E-Jurnal Akuntansi, 29(3), 912. https:// doi.org/10.24843/eja.2019.v29.i03.p01

Dhamara, G. P., \& Violita, E. S. (2018). The influence of financial distress and independence of board of commissioners on tax aggressiveness. 55(Iac 2017), 81-86. https:// doi.org/10.2991/iac-17.2018.15

Edwards, A., Schwab, C., \& Shevlin, T. (2016). Financial constraints and cash tax savings. Accounting Review, 91(3), 859-881. https://doi.org/10.2308/accr51282

Farooq, U., \& Jibran, A. Q. (2017). Scope, measurement, impact size and determinants of indirect cost of financial distress: a systematic literature review. Qualitative Research in Financial Markets. https://doi.org/10.1108/QRFM-08-2017-0080

Ferramosca, S., \& Ghio, A. (2018). Accounting conservatism in family firms. Contributions to Management Science, 139-164. https:/ / doi.org/10.1007/978-3319-73588-7_4

Givoly, D., \& Hayn, C. (2000). The changing time-series properties of earnings, cash flows and accruals. Journal of Accounting and Economics, 29, 287-320. https://doi.org/10.1016/S0165-4101(00)00024-0

Hajawiyah, A., Wahyudin, A., Kiswanto, Sakinah, \& Pahala, I. (2020). The effect of good corporate governance mechanisms on accounting conservatism with leverage as a moderating variable. Cogent Business and Management, 7(1), 113. https:/ / doi.org/10.1080/23311975.2020.1779479

Hayes, A. F. (2015). An index and test of linear moderated mediation. Multivariate Behavioral Research, 50(1), 37-41. https:/ / doi.org/10.1080/00273171.2014.962683

Lawal, A., \& Hassan, S. U. (2021). Moderating effect of financial constraint on relationship between accounting conservatism and investment efficiency of Nigerian consumer goods firms. 1(1), 25-42. https:/ / doi.org/10.47747/jat.v1i1.435 
Lenz, H. (2018). Aggressive tax avoidance by managers of multinational companies as a violation of their moral duty to obey the law: A kantian rationale. Journal of Business Ethics, 165(4), 681-697. https://doi.org/10.1007/s10551-018-4087-8

Lietz, G. (2013). Tax avoidance vs. tax aggressiveness: A unifying conceptual framework. SSRN. https://doi.org/10.2139/ssrn.2363828

Martinez, A. L. (2021). Tax aggressiveness as a determining factor of accounting conservatism in Brazil. June. https://doi.org/10.2139/ssrn.3857770

Nadhifah, M., \& Arif, A. (2020). Transfer pricing, thin capitalization, financial distress, earning management, dan capital intensity terhadap tax avoidance dimoderasi oleh sales growth. Jurnal Magister Akuntansi Trisakti, 7(2), 145. https://doi.org/10.25105/jmat.v7i2.7731

Pramudito, B. W., \& Sari, M. M. R. (2015). Pengaruh konservatisme akuntansi, kepemilikan manajerial dan ukuran dewan komisaris terhadap tax avoidance. E-Jurnal Akuntansi, 13(3), 737-752.

Pratama, I. R. (2020, November 4). Laporan mesin uang Makau: Ada kebocoran pajak ekspor pulp larut $R p \quad 1,9$ triliun . Tribun News. https://www.tribunnews.com/nasional/2020/11/04/laporan-mesin-uangmakau-ada-kebocoran-pajak-ekspor-pulp-larut-rp-19-triliun

Purnaningsih, N. K. C., \& Noviari, N. (2019). Pengaruh penerapan e-filling terhadap kepatuhan wajib pajak orang pribadi. E-Jurnal Akuntansi Udayana, 1838-1854. https://doi.org/10.24843/EJA.2019.v28.i03.p13

Rachmawati, N. A., \& Fitriana, A. (2021). The effect of financial constraints and institutional ownership on tax agressiveness. ACCRUALS (Accounting Research Journal of Sutaatmadja), 5(01), 38-53. https://doi.org/10.35310/accruals.v5i01.606

Richardson, G., Lanis, R., \& Taylor, G. (2015a). Financial distress, outside directors and corporate tax aggressiveness spanning the global financial crisis: An empirical analysis. Journal of Banking and Finance, 52, 112-129. https:/ / doi.org/10.1016/j.jbankfin.2014.11.013

Richardson, G., Lanis, R., \& Taylor, G. (2015b). The impact of financial distress on corporate tax avoidance spanning the global financial crisis: Evidence from Australia. Economic Modelling, 44, 44-53. https://doi.org/10.1016/j.econmod.2014.09.015

Rosadi, R. A., \& Waluyo, I. (2017). Pengaruh gender, tekanan ketaatan, tekanan anggaran waktu dan pengalaman audit terhadap audit judgment. Nominal:Barometer Riset Akuntansi Dan Manajemen, 6(1), 124-135. https://doi.org/10.21831/nominal.v6i1.14337

Sadjiarto, A., Hartanto, S., Natalia, \& Octaviana, S. (2020). Analysis of the effect of business strategy and financial distress on tax avoidance. Journal of Economics and Business, 3(1). https:// doi.org/10.31014/aior.1992.03.01.193

Saleh, M., Kurniaty, \& Muhsin. (2019). Looking for empirical evidence between accounting conservatism and ownership structure towards the aggressive tax avoidance in public listed companies of Indonesia. 10(10), 21-26. https://doi.org/10.7176/RJFA

Sarra, H. D. (2017). Pengaruh konservatisme akuntansi, komite audit dan dewan komisaris independen terhadap penghindaran pajak (studi empiris pada 
industri kimia dan logam di Bursa Efek Indonesia periode 2010-2014). Competitive Jurnal Akuntansi Dan Keuangan, 1(1), 63. https://doi.org/10.31000/competitive.v1i1.108

Sholikhah, R. M., \& Suryani, A. W. (2020). The influence of the financial distress, conflict of interest, and litigation risk on accounting conservatism. KnE Social Sciences, 2020, 222-239. https:/ / doi.org/10.18502/ kss.v4i7.6854

Sjahputra, A. (2019). Determinan tax avoidance pada perusahaan food and beverages di Indonesia. Scientific Journal of Reflection, 2(4), 371-380. https://doi.org/10.5281/zenodo.3472234

Suandy, E. (2016). Perencanaan Pajak (6th ed.). Salemba Empat.

Sundari, N., \& Aprilina, V. (2017). Pengaruh konservatisme akuntansi, intensitas aset tetap, kompensasi rugi fiskal dan corporate governance terhadap tax avoidance. JRAK: Jurnal Riset Akuntansi Dan Komputerisasi Akuntansi, 8(1), 85109.

Susanti, C. M. (2018). Pengaruh konservatisme, leverage, profitabilitas, ukuran perusahaan terhadap tax avoidance. Jurnal Informasi, Perpajakan, Akuntansi, Dan Keuangan Publik, 13(2), 181. https://doi.org/10.25105/jipak.v13i2.5021

Swandewi, N. P., \& Noviari, N. (2020). Pengaruh financial distress dan konservatisme akuntansi pada tax avoidance. E-Jurnal Akuntansi, 30(7), 1670. https://doi.org/10.24843/ eja.2020.v30.i07.p05

Valensia, K., \& Khairani, S. (2019). Pengaruh profitabilitas, financial distress, dewan komisaris independen dan komite audit terhadap nilai perusahaan dimediasi oleh tax avoidance (Studi empiris pada perusahaan sektor industri barang konsumsi yang terdaftar di Bursa Efek Indonesia periode 2. Jurnal Akuntansi, 9(1), 47-64. https://doi.org/10.33369/j.akuntansi.9.1.47-64

Windaryani, I. G. A. I., \& Jati, I. K. (2020). Pengaruh ukuran perusahaan, kepemilikan institusional, dan konservatisme akuntansi pada tax avoidance. E-Jurnal Akuntansi, 30(2), 375. https:/ / doi.org/10.24843/ eja.2020.v30.i02.p08

$\mathrm{Wu}$, A. D., \& Zumbo, B. D. (2008). Understanding and using mediators and moderators. Social Indicators Research, 87(3), 367-392. https://doi.org/10.1007/s11205-007-9143-1

Zulfiara, P., \& Ismanto, J. (2019). Pengaruh konservatisme akuntansi dan penghindaran pajak terhadap nilai perusahaan. Profita: Komunikasi Ilmiah Akuntansi Dan Perpajakan, 13(1), 1-18. https://doi.org/10.32493/jabi.v2i2.y2019.p134-147 